\title{
CPCP: Colorado Plateau Coring Project - 100 Million Years of Early Mesozoic Climatic, Tectonic, and Biotic Evolution of an Epicontinental Basin Complex
}

\author{
by Paul E. Olsen, Dennis V. Kent, and John W. Geissman
}

doi:10.2204/iodp.sd.6.12.2008

\section{Introduction}

Early Mesozoic epicontinental basins of western North America contain a spectacular record of the climatic and tectonic development of northwestern Pangea as well as what is arguablytheworld'srichestandmost-studied Triassic-Jurassic continental biota. The Colorado Plateau and its environs (Fig. 1) expose the textbook example of these layered sedimentary records (Fig. 2). Intensely studied since the mid-nineteenth century, the basins, their strata, and their fossils have stimulated hypotheses on the development of the Early Mesozoic world as reflected in the international literature. Despite this long history of research, the lack of numerical time calibration, the presence of major uncertainties in global correlations, and an absence of entire suites of environmental proxies still loom large and prevent integration of this immense environmental repository into a useful global picture. Practically insurmountable obstacles to outcrop sampling require a scientific drilling experiment to recover key sedimentary sections that will transform our understanding of the Early Mesozoic world.

To bring our insight into this critical time in Earth history to a new level, we developed the concept of the Colorado Plateau Coring Project (CPCP), an effort to recover continuous core spanning the early Mesozoic (Triassic-Jurassic) section of the Colorado Plateau and adjacent areas. The original basis for this was outlined at the 1999 International

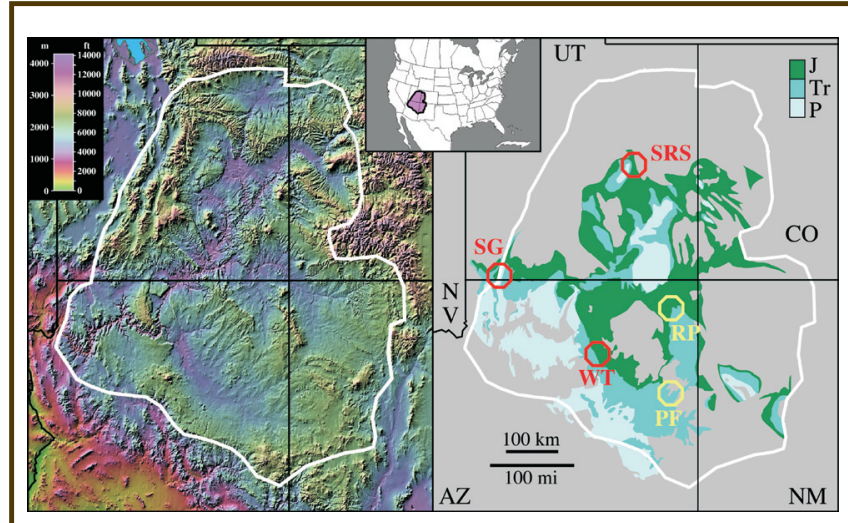

Figure 1. Map of the Colorado Plateau (white line) and adjacent areas: [Left] Shaded digital elevation map (courtesy of Andrew D. Birrell http://birrell.org/andrew/reliefMaps/ and http://birrell.org/andrew/ copyright.html); [Right] Generalized geological map showing Permian and Triassic and Jurassic strata (modified from R. Blakely http://jan. ucc.nau.edu/ rcb7/Jurassic_erg_graphics.html). Core areas are: PF, Petrified Forest, Arizona; RP, Rock Point, Utah; SG, St. George, Utah; WT, Ward Terrace, Arizona; SRS, San Rafael Swell, Utah.
Continental Scientific Drilling Program (ICDP) and U.S. National Science Foundation (NSF) funded International Workshop for a Climatic, Biotic, and Tectonic, Pole-to-Pole Coring Transect of Triassic-Jurassic Pangea (http://www. ldeo.columbia.edu/ polsen/nbcp/pangeafinalreport.html, Olsen et al., 1999), section "Western Equatorial Pangea" (http://www.ldeo.columbia.edu/ polsen/nbcp/westpangea. html). Forty-five researchers from six countries attended the inaugural CPCP planning workshop held 13-16 November 2007 , in St. George, Utah. The main goal was to develop a community consensus science plan for the CPCP (http:// www.ldeo.columbia.edu/ polsen/cpcp/CPCP_home_page. $\mathrm{html})$. The participants represented disciplines ranging from geochronology and physical stratigraphy through vertebrate paleontology and paleobotany. A plenary session with speakers highlighting the major science issues, precedents, and geoinformatics priorities was followed by thematic breakout groups. These included Stratigraphy, Geochronology and Magnetostratigraphy, Climate and Environments, Paleontology and Biotic Change, and Geoinformatics and Core-log Outcrop Integration. A half-day field trip was made to the St. George Dinosaur Discovery Site at Johnson Farm (http://www.sgcity.org/dinotrax/) and Warner Valley outcrops of Triassic-Jurassic strata (Fig. 3), and was followed by a plenary synthesis session. As developed by consensus at the workshop, the goal of the CPCP is to transform our understanding of the interplay between major biotic transitions, global climate change, plate position, and tectonics over 100 Ma of Earth histories (Fig. 2).

\section{Overall Concept and Goals}

Broad questions that could be profitably addressed in the Colorado Plateau venue include the following: what are the global or regional climate trends vs. plate position changes in "hot house" Pangea; how do largely fluvial systems respond to cyclical climate; what are the rates and magnitudes of the transition from the Paleozoic to essentially modern terrestrial ecosystems; and how does the stratigraphy reflect the interplay between growth in accommodation, uplift, and eustatic fluctuations? Based on these questions, the workshop identified eight goals attainable by coring of key Triassic/Jurassic sections:

1) Establishment of paleogeographic boundary conditions, particularly changes in paleolatitude. 


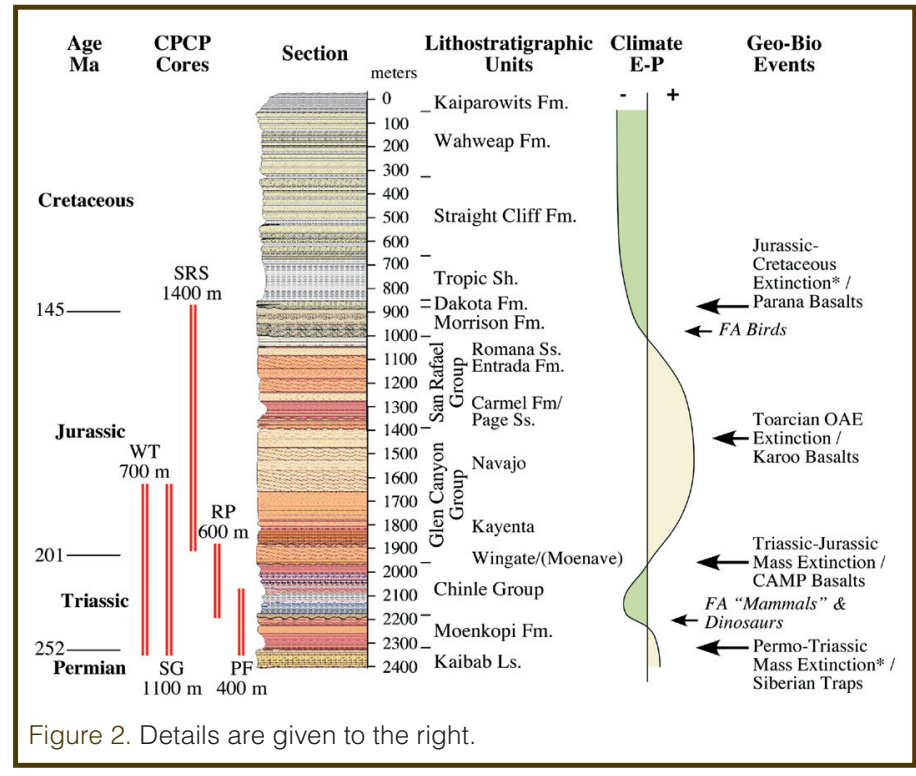

2) Development of the highest-resolution magnetic polarity stratigraphy for Early Triassic through Late Jurassic strata to facilitate detailed regional and global correlation.

3) Determination of how paleoclimates are expressed through time in the sedimentary record of western Pangea.

4) Identification of the precise stratigraphic position of major global biotic transitions (i.e., Permo-Triassic, Triassic-Jurassic, and Toarcian)

5) Refinement of lithostratigraphic and biostratigraphic correlations, considering regional unconformities and their possible relationship to eustacy and tectonics (c.f., Bachmann and Kozur, 2004).

6) Development of a chemostratigraphic $\left(\delta^{13} \mathrm{C}\right.$, cuticular $\mathrm{CO}_{2}$ proxy, $\mathrm{Nd}$, $\mathrm{Sr}$, clays, etc.) reference sections.

7) Improvement of U-Pb zircon provenance stratigraphy and geochronology of ash beds.

8) Establishment of links among the temporal evolution of the Colorado Plateau sedimentary record, rifting of Pangea opening of the Atlantic Ocean, and emplacement of basalt provinces (Fig. 2).

\section{Coring Plans}

Given these overall goals, the workshop reached several conclusions that dictated the coring plan.

1) Early Triassic through Late Jurassic Formations including the Morrison Formation should be cored in order to cover the full range of climatic milieus represented by these rocks. Collectively, the group defined a three-tiered coring plan consisting of (1) three relatively thick $(\sim 1 \mathrm{~km})$ synoptic intervals that together would yield an overlapping stratigraphic framework for the entire Jurassic and Triassic section, (2) two thinner $(<500 \mathrm{~m})$ cored sections that would tie to critical outcrop areas or to expanded critical intervals, and (3) a number of short sections to address more specific problems or provide regional coverage to the other five cores that are the nexus of the project.
Generalized Colorado Plateau section (Glen Canyon/Kaiparowits Plateau, based on http://jan.ucc.nau.edu/ rcb7/Glen_Can.jpg) with the cored sections recommended by the CPCP workshop participants, a generalized evaporation-precipitation (E-P) curve loosely based on climate sensitive facies, and some major geological and biological events ( ${ }^{*}$ actual boundary may or may not be present in rock section). See Fig. 1 for core area abbreviations. Note that the relative thicknesses of various stratigraphic units are generally different than what is shown in the color section and not the same between different coring areas.

The five major stratigraphic units shown here were deposited under dramatically changing climatic conditions that constitute the Triassic and Jurassic of the Colorado Plateau: the Early to Middle Triassic Moenkopi Formation (marginal marine and coastal sabka to semiarid fluvial and floodplain, minor eolian); the Late Triassic Chinle Group (humid to semiarid fluvial to lacustrine, some eolian near top); the latest (?) Triassic-Early Jurassic Glen Canyon Group (semiarid to arid, major eolian, fluvial, lacustrine); the Middle to Late Jurassic San Rafael Group (marine to coastal sabka, major eolian and fluvial arid to semiarid; from http://www.nps.gov/ arch/); and the Late Jurassic Morrison Formation (semiarid to humid, fluvial and lacustrine). Determining the precise nature and origin of the large climatic transitions represented by these units is a major goal of the CPCP.

2) Superposition is paramount. Evaluation of the critical Early Mesozoic transitions is required of all Early Mesozoic units in clear superposition. The five major stratigraphic units identified as major coring targets reflect, from oldest to youngest: arid (Moenkopi); humid to semiarid (Chinle); very arid (Glen Canyon and San Rafael); and return to semiarid and humid (Morrison) (Figs. 2 and 4). These climate transitions have been explained in several ways-translation of the North American plate from equatorial to mid-latitudes through zonal climate belts (Dickinson, 2005; Kent and Muttoni, 2003; Kent and Tauxe, 2004); large scale changes in the climate system involving changes in the non-zonal components of the climate system, particularly the monsoon (Kutzbach and Gallimore, 1989; Parrish, 1995; Rowe et al., 2007); or fluctuations in greenhouse gases like $\mathrm{CO}_{2}$ (e.g., McElwain et al., 1999; Kürschner, 2001). These fundamentally different hypotheses remain untested because the temporal evolution of major boundary conditions, most notably latitude, has not been resolved to a useful level of precision (Tauxe and Kent, 2004; Tan et al., 2007).

3) Internal time calibration needed. Correlation of the Plateau sequence is presently based on low-resolution non-marine biostratigraphic approaches, and it does not provide clear biogeographic patterns or determination of the rates of biotic change in these very fossiliferous sequences. None of the major intervals of biotic change (Permo-Triassic; Triassic-Jurassic; or Toarcian) are located with precision in this succession. A combination of polarity stratigraphy along with geochronologic dates from ash deposits and dispersed grains will allow global correlations, including: 1) Triassic and Early Jurassic reference sections (Szurlies, 2007); 2) the astronomically calibrated polarity time scale (Kent and Olsen, 1999, 2008; Olsen and Kent, 1999; Hounslow et al., 2004; Kemp and Coe, 2007); 3) the Germanic basin (Bachmann and Kozur, 2004); 4) fully marine Tethyan sections (Muttoni et al., 2005; Channell et al., 2003; Gallet et al., 2007); 5) non-marine Jurassic to Early Cretaceous sequences of China (Feursich et al., 2002; Yao et al., 2003; Xu, 2005); 
and 6) possibly, the marine magnetic anomaly M-sequence (Channell et al., 1995; Sager et al., 1998).

4) Minimize hiatuses. Acquiring as much stratigraphic scope as possible through the more continuous units and testing any paleomagnetic reversal sequences across geography by designing stratigraphic overlap between cores will help overcome significant unconformities and possible smaller and cryptic hiatuses. The thickest sections, least likely to be affected by rampant hiatuses, are not confined to a single area in the Colorado Plateau because of lateral shifts in the basin's depocenters. Several cores will be necessary to get the most favorable sections of each of the units. However, the thick sections proposed for coring are far from comparable surface outcrops, and thus, subsidiary sections more proximal to sources of the surface data must be cored as well. The goal is to provide a long enough section with unambiguous ties to the outcrop and sufficient stratigraphic scope to correlate with the main, long cores.

5) Thick eolianite successions should be avoided while key limestone and eolianite tongues must be intersected for age control by lateral correlation to outcrop.

Using these five principles above, three areas identified for long $(\sim 1 \mathrm{~km})$ cores are, from the uppermost stratigraphic interval downward (Figs. 1 and 2): 1) Dry Mesa (east side of San Rafael Swell, UT), $1400 \mathrm{~m}$ from basal Cretaceous Cedar Mountain Formation to the Permian Kaibab Formation; 2) St. George (west of the Hurricane fault), $1100 \mathrm{~m}$ from locally basal Navajo Formation to Permian Kaibab Formation; and 3) Tuba City (north of Ward Terrace): 700 m from basal Navajo Formation to Kaibab Formation. Although the

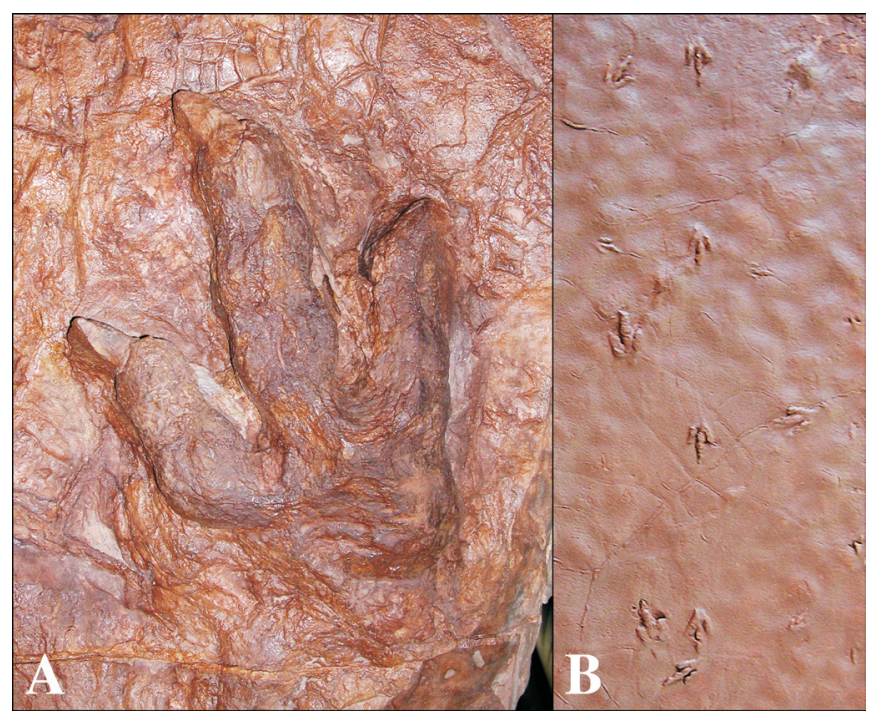

Figure 3. Examples of dinosaur tracks at the St. George Discovery Site at Johnson Farm in the lower Whitmore Point Member of the Moenave Formation: [A] Example of natural cast of Eubrontes giganteus ( $35 \mathrm{~cm}$ long), plausibly made by a large theropod dinosaur similar to Dilophosaurus from the lower Kayenta Formation; [B] small theropod dinosaur footprints of the "Grallator" and "Anchisauripus" types ( 10-15 cm long each). The importance of these fossil assemblages is that they document the terrestrial assemblages just after the Triassic-Jurassic extinction event that surprisingly is overwhelmingly dominated by carnivores.
St. George and Tuba City sections appear to span the same overall section, they are actually critical complements. The Moenkopi and latest (?) Triassic-Early JurassicTriassic-Early Jurassic Moenave formations are well-developed, cyclical, and probably relatively complete in the St. George area, yet the Chinle Group is very thin and erosionally truncated. In the Tuba City area, the Chinle is very well-developed, but the Moenkopi is very thin and erosionally truncated. Also, the Moenave lacks the well-developed, cyclical lacustrine strata present around St. George.

The two medium depth sections (Fig. 2) are targeted for 1) the Rock Point area (north of Round Rock, Utah), $\sim 600 \mathrm{~m}$ from basal Wingate Formation to Permian Kiabab Formation,

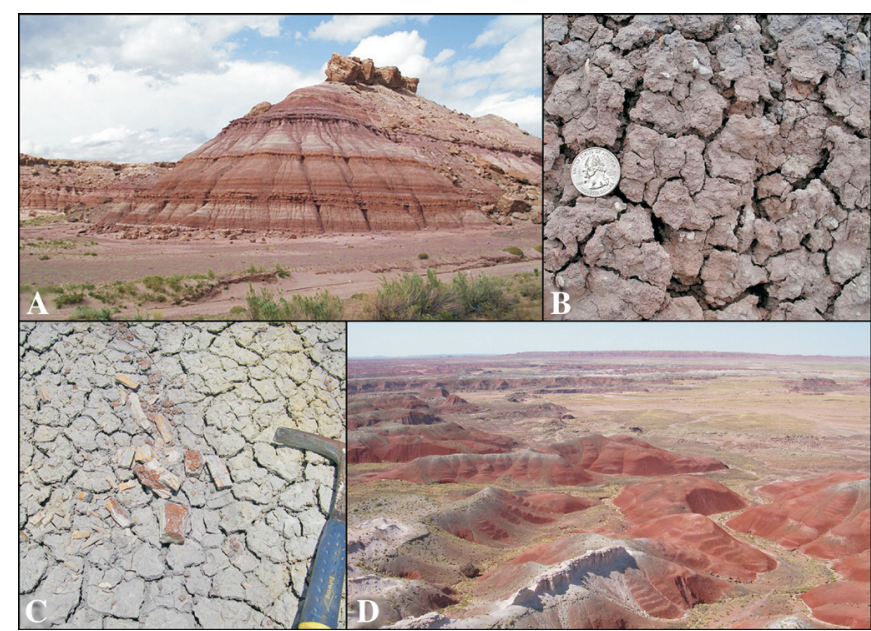

Figure 4. Details are given below.

Although the American Southwest, including the Colorado Plateau, is famous for spectacular exposures in striking badlands, the thickest sections of key time intervals are often projected from the subsurface. The most continuous sections in outcrop are often exposed as inaccessible vertical cliffs or are heavily weathered and geochemically altered, precluding research at the appropriate level of detail. Because of low bedding dips, the assembly of sections spanning large stratigraphic thicknesses requires long-distance traverses that often compromise the essential assumption of superposition because of facies changes. The problems are amply revealed by repeated attempts in the literature at compiling long, high-resolution sections that describe the succession in any specific area. Long, continuously cored intervals tied to outcrop in key areas are required for further substantial progress.

Opportunities and problems of working only with outcrops present themselves in examples of superb near- $100 \%$ outcrops, especially of muddy facies (Fig. 4). Mudstones are often bentonitic and with a partial volcanic source, which means there are datable ashes; however, it also means that the outcrop surfaces present horrendous sampling problems where freshness and physical integrity are at a premium as for geochemistry or paleomagnetics. Two examples include the Late Jurassic Morrison Formation (Fig. 4A and 4B) and the Late Triassic Chinle Group (Fig. 4C and 4D).

Fig. 4A, Brushy Basin Member of the Morrison Formation west of Green River, Utah (from http://en.wikipedia.org/wiki/Morrison_Formation); Fig. 4B, typical "popcorn" surface of bentonitic mudstone of the Brushy Basin Member of the Morrison Formation west of Green River, Utah (same source as 4A); Fig. 4C, "popcorn" surface of the Chinle Group near Bluewater Creek, NM (Stop 1 of Lucas et al., 2007), with fragmentary weathered metoposaur amphibian dermal bones; and Fig. 4D, outcrops of bentonitic Painted Desert Member of the Petrified Forest Formation of the Chinle Group in Petrified Forest National Park with the U-Pb dated Black Forest Bed (Riggs et al., 2003) outcropping as the white bed in foreground. 
and 2) the Petrified Forest area (within Petrified Forest National Park, AZ), $400 \mathrm{~m}$ from Sonsela (mid-Chinle) to Permian. The Rock Point area is a critical target because it exposes the Triassic-Jurassic boundary section in the largely eolian Wingate Formation, based on both vertebrate paleontology and magnetostratigraphy, and it is a natural complement to the lacustrine-dominated Moenave Formation near St. George. The Petrified Forest area has produced the bulk of the Chinle fauna and flora, as well as dated ash beds, and it is a natural complement to the Chinle section in the Tuba City area. The workshop concluded that the geophysical $\log$ s of the core holes and cores will be critical in tying cores to outcrop (Szurlies et al., 2003).

\section{Next Steps}

The CPCP workshop endorsed aiming full drilling proposals to ICDP and U.S.

National Science Foundation (NSF) Continental Dynamics. In preparation for this, there will be an international CPCP proposal planning workshop in Albuquerque, N.M., to be advertised in the near future.

\section{References}

Bachmann, G.H., and Kozur, H.W., 2004. The Germanic Triassic: correlations with the international chronostratigraphic scale, numerical ages and Milankovitch cyclicity. Hallesches Jahrbuch Geowissenschaften B, 26:17-62.

Channell, J.E.T., Erba, E., Nakanishi, M., and Tamaki, K., 1995. Late Jurassic-Early Cretaceous time scales and oceanic magnetic anomaly block models. In Berggren, W.A., Kent, D.V., Aubry, M.-P., and Hardenbol, J. (Eds.), Geochronology, Time Scales and Global Stratigraphic Correlations. Tulsa, Okla. (SEPM (Society for Sedimentary Geology)) SEPM Special Volume No. 54, p. 51-63.

Channell, J.E.T., Kozur, H.W., Sievers, T., Mock, R., Aubrecht, R., and Sykora, M., 2003. Carnian-Norian biomagnetostratigraphy at Silicka Brezova (Slovakia): correlation to other Tethyan sections and to the Newark Basin: Palaeogeogr. Palaeoclimatol. Palaeoecol., 191:65-109.

Dickinson, W.R., 2005. Redbed paleomagnetism and Mesozoic paleolatitude of the Colorado Plateau. Geol. Soc. Am. Abst. Prog.,
Data management scenario for the CPCP showing the relationship between data gathering (i.e., from the cores and core holes) and the flow of information and samples derived from it to community access systems. Acronyms are: DIS, Drilling Information System; CoreWall, a real-time stratigraphic correlation, core description and data visualization system (http://www.evl.uic.edu/cavern/corewall/index.php); SESAR, System for Earth Sample Registration (http://www. geosamples.org/); PaleoStrat, a community digital information system for paleontology and sedimentary geology (https://www. paleostrat.com/); IGSN, International Geo Sample Number; SDDB, The Scientific Drilling Database is the repository for data from operations of ICDP (http://www.icdponline.org/contenido/lakedb/front_content. php); EarthChem, system to facilitate the preservation, discovery, access, and visualization of geochemical datasets (http://www. earthchem.org/); MaglC, Magnetics Information Consortium (http://www.earthref. org/MAGIC/). A robust and effective data management/geoinformatics system, accessible through a CPCP Data Portal, will facilitate and support the science and provide the basis for education and outreach efforts. This will include coupling the Drilling Information System (DIS) of the ICDP with System for Earth Sample Registration (SESAR; www. geosamples.org), EarthChem (www. earthchem.org), CoreWall (www.evl.uic.edu/ cavern/corewall), and PaleoStrat (www. paleostrat.org), a core-core hole-log integration system, and a novel digital framework of regional geology (Fig. 5).

\section{7(7):362.}

Feursich, F.T., Sha, J.G., Jiang, B.Y., and Pan, Y.H., 2002. High resolution palaeoecological and taphonomic analysis of Early Cretaceous lake biota, western Liaoning (NE-China). Palaeogeogr. Palaeoclimatol. Palaeoecol., 253:434-457.

Gallet, Y., Krystyn, L., Marcoux, J., and Besse, J., 2007. New constraints on the End-Triassic (Upper Norian-Rhaetian) magnetostratigraphy. Earth Planet. Sci. Lett., 255:458-470.

Hounslow, M.W., Posen, P.E., and Warrington, G., 2004. Magnetostratigraphy and biostratigraphy of the Upper Triassic and lowermost Jurassic succession, St. Audrie's Bay, UK. Palaeoceanogr. Palaeoclimatol. Palaeoecol., 213:331-358.

Kemp, D.B., and Coe, A.L., 2007. A nonmarine record of eccentricity forcing through the Upper Triassic of southwest England and its correlation with the Newark Basin astronomically calibrated geomagnetic polarity time scale from North America. Geology, 35(11):991-994.

Kent, D.V., and Muttoni, G., 2003. Mobility of Pangea: Implications for Late Paleozoic and Early Mesozoic paleoclimate. In LeTourneau, P.M., and Olsen, P.E. (Eds.), The Great Rift Valleys of Pangea in Eastern North America, Volume 1, Tectonics, Structure, and Volcanism. New York (Columbia University Press),11-20.

Kent, D.V., and Olsen, P.E., 1999. Astronomically tuned geomagnetic polarity time scale for the Late Triassic. J. Geophys. Res., 
104:12831-12841.

Kent, D.V., and Olsen, P.E., 2008. Early Jurassic magnetostratigraphy and paleolatitude from the Hartford continental rift basin (eastern North America): Testing for polarity bias and abrupt polar wander in association with the Central Atlantic Magmatic Province. J. Geophys. Res., 113, B06105, doi:10.1029/2007JB005407.

Kent, D.V., and Tauxe, L., 2005. Corrected Late Triassic latitudes for continents adjacent to the North Atlantic. Science, 307:240-244.

Kürschner, W.M., 2001. Leaf sensor for $\mathrm{CO}_{2}$ in deep time. Nature, 411:247-248.

Kutzbach, J.E., and Gallimore, R.G., 1989. Pangean climates: megamonsoons of the megacontinent. J. Geophys. Res., 94:3341-3357.

Lucas, S.J., Heckert, A.B., Spielmann, J.A., Tanner, L.H., and Hunt, A.P., 2007. First Day: Middle and Upper Triassic stratigraphy, sedimentology, and paleontology of west-central New Mexico. In Lucas, S.J., and Spielmann, J.A. (Eds.), Triassic of the American West, New Mexico Museum of Natural History \& Science Bulletin 40, 169-180.

McElwain, J.C., Beerling, D.J., and Woodward, F.I., 1999. Fossil plants and global warming at the Triassic-Jurassic boundary. Science, 285(5432):1386-1390.

Muttoni, G., Meco, S., and Gaetani, M., 2005. Magnetostratigraphy and biostratigraphy of the Late Triassic Guri Zi Section, Albania: Constraint on the age of the Carnian-Norian boundary. Rivista Italiana di Paleontologia e Stratigrafia, 111:233 -245 .

Olsen, P.E., and Kent, D.V., 1999. Long-period Milankovitch cycles from the Late Triassic and Early Jurassic of eastern North America and their implications for the calibration of the early Mesozoic time scale and the long-term behavior of the planets. Phil. Trans. Roy. Soc. London A, 357:1761-1787.

Olsen, P.E., Kent, D.V., and Raeside, R., 1999. International workshop for a climatic, biotic, and tectonic, pole-to-pole coring transect of Triassic-Jurassic Pangea. Newsletter, ICDP (Potsdam), 1:16-20.

Parrish, J.T., 1995. Geologic evidence of Permian climate. In Scholle, P.A., Peryt, T.M., and Ulmer-Scholle, D.S. (Eds.), The Permian of Northern Pangea, Paleogeogr., Paleoclimatol. Stratigr. vol. 1, Berlin (Springer Verlag), 53-61.

Riggs, M.R., Ash, S.R., Barth, A.P., Gehrels, G.E., and Wooden, J.L., 2003. Isotopic age of the Black Forest Bed, Petrified Forest Member, Chinle Formation, Arizona: An example of dating a continental sandstone. Geol. Soc. Am. Bull., 115:1315-1323.

Rowe, C.M., Loope, D.B., Oglesby, R.J., Van der Voo, R., and Broadwater, C.E., 2007. Inconsistencies between Pangean reconstructions and basic climate controls. Science, 318:1284-1286.

Sager, W.W., Weiss, M.A., Tivey, M.A., and Johnson, H.P., 1998. Geomagnetic polarity reversal model of deep-tow profiles from the Pacific Jurassic "Quiet Zone" J. Geophys. Res., 103:5269-5286.

Szurlies, M., Bachmann, G.H., Menning, M., Nowaczyk, N.R., and Käding, K.-C., 2003. Magnetostratigraphy and high-resolution lithostratigraphy of the Permian-Triassic boundary interval in Central Germany. Earth Planet. Sci. Lett.,
212(3-4):263-278.

Szurlies, M., 2007. Latest Permian to Middle Triassic cyclo- magnetostratigraphy from the Central European Basin, Germany: Implications for the geomagnetic polarity timescale: Earth Planet. Sci. Lett., 261:602-619.

Tan, X., Kodama, K.P., Gilder, S., and Courtillot, V., 2007. Rock magnetic evidence for inclination shallowing in the Passaic Formation red beds from the Newark basin and a systematic bias of the Late Triassic apparent polar wander path for North America. Earth Planet. Sci. Lett., 254:345-357.

Tauxe, L., and Kent, D.V., 2004. A simplified statistical model for the geomagnetic field and the detection of shallow bias in paleomagnetic inclinations: Was the ancient magnetic field dipolar? In Channell, J.E.T., Kent, D.V., Lowrie, W., and Meert, J. (Eds), Timescales of the Paleomagnetic Field, AGU Geophysical Monograph 145,101-115.

Xu, D.Y., 2005. Astro-geologic time scale and the advancements of cyclostratigraphy. J. Stratigr., 29:635-640 (in Chinese with English abstract).

Yao, Y.-M., Fu, G.-B., Xu, D.-Y., Qin, J., and Yao, S., 2003. Preliminary study on the high-resolution cyclostratigraphy of the Jurassic system in Turpan-Hami basin, Xinjiang. J. Stratigr., 27:122-128 (in Chinese with English abstract).

\section{Authors}

Paul E. Olsen, Lamont-Doherty Earth Observatory (LDEO) of Columbia University, 61 Route 9W, Palisades, N.Y., 10964-1000, U.S.A., e-mail: polsen@1deo.columbia.edu. Dennis V. Kent, Department of Earth \& Planetary Sciences, Rutgers University, 610 Taylor Road, Piscataway, N.J. 08854, U.S.A. and Lamont-Doherty Earth Observatory, 61 Route 9W, Palisades, N.Y. 10964,, U.S.A.

John W. Geissman, Department of Earth and Planetary Sciences, University of New Mexico, Albuquerque, N.M., 87131, U.S.A.

\section{Related Web Links}

http://www.earthchem.org/ http://www.earthref.org/MAGIC/

http://www.evl.uic.edu/cavern/corewall/index.php http://www.geosamples.org/

http://www.icdp-online.org/contenido/lakedb/front _content.php

http://www.ldeo.columbia.edu/ polsen/cpcp/CPCP_ home_page.html

http://www.ldeo.columbia.edu/ polsen/cpcp/CPCP_ dosecc_nsf.html

http://www.ldeo.columbia.edu/ polsen/nbcp/pangeafinalreport.html

http://www.ldeo.columbia.edu/ polsen/nbcp/westpangea. $\mathrm{html}$

https://www.paleostrat.com/

http://www.sgcity.org/dinotrax/

\section{Figure Credits}

Fig. 1: courtesy of Andrew D. Birrell http://birrell.org/ andrew/reliefMaps/ and http://birrell.org/andrew/copyright.html 